Research Article

\title{
Short Cantilever Rock Beam Structure and Mechanism of Gob-Side Entry Retaining Roof in Reuse Period
}

\author{
Jingke Wu $\mathbb{D}^{1,},{ }^{1,2,3}$ Yun Dong, ${ }^{1}$ Jiarui Chen $\mathbb{D}^{1},{ }^{1}$ Chunlei Zhang $\mathbb{D},{ }^{1}$ Wei Yin $\mathbb{D}^{1},{ }^{1}$ \\ JiHua Zhang $\mathbb{D}$, ${ }^{1}$ and Yongzhen Cheng $\mathbb{D}^{1}$ \\ ${ }^{1}$ Faculty of Architecture and Civil Engineering, Huaiyin Institute of Technology, Huai'an, Jiangsu 223001, China \\ ${ }^{2}$ Jiangsu Baoli International Investment Co., Ltd, Jiangyin, Jiangsu 214400, China \\ ${ }^{3}$ School of Transportation, Southeast University, Nanjing, Jiangsu 211189, China \\ Correspondence should be addressed to Jingke Wu; wujingke@hyit.edu.cn
}

Received 21 September 2020; Revised 12 October 2020; Accepted 19 October 2020; Published 31 October 2020

Academic Editor: Xuesheng Liu

Copyright (c) 2020 Jingke Wu et al. This is an open access article distributed under the Creative Commons Attribution License, which permits unrestricted use, distribution, and reproduction in any medium, provided the original work is properly cited.

In the reuse stage of a gob-side entry retaining, failure of the structure and stability of the main roof have a significant effect on the safety of the advanced support and ventilation space at the working face. In this study, field investigation, theoretical analysis, and industrial experimentation were performed to analyse the fracture characteristics and formation process of the gob-side entry retaining roof during the reuse period. A dynamic-equilibrium mechanical model of the main roof structure is presented and the formation mechanisms of different types of short cantilever rock beam structures are clarified. The following major conclusions are drawn: (1) Three types of short cantilever rock beam structures occur in the main roof of a gob-side entry retaining during the reuse period, namely, the "short cantilever-articulated rock beam" structure, "short cantilever step rock beam (type I)" structure, and "short cantilever step rock beam (type II)" structure. (2) The stability criterion for these three short cantilever rock beam structures was also determined; that is, when the sliding instability coefficient $K \geq 1$, the short cantilever-articulated rock beam structure will form, and when the sliding instability coefficient $K<1$, the short cantilever step rock beam (type I or II) will form. (3) The governing law for the thicknesses of the main roof, immediate roof, and coal seam of the short cantilever rock beam structure was clarified; namely, the $K$-value gradually increases with increases in the thickness of the coal seam, drops sharply and then decreases gradually with increases in the thickness of the main roof, and decreases slowly with increases in the thickness of the immediate roof. The research results were validated at the gob-side entry retaining project in the Huainan mining area and have theoretical significance and reference value for roadway support projects with similar conditions.

\section{Introduction}

With the continuous improvements in coal mining methods and mechanical equipment, gob-side entry retaining has become an important factor in the scientific and technical development of coal mining in China $[1,2]$. This technique has been widely applied and has a prominent position in China's coal industries, including the China Energy Investment Group, Shandong Energy Xinwen Mining Group, China Pingmei Shenma Group, Jizhong Energy Group, and Huainan Mining Group. Numerous achievements have been made in the control theory and support technology of gobside entry retaining in recent years. For example, Kang et al.
$[3,4]$ proposed a support design principle for gob-side entry retaining based on the analysis of the deformation failure characteristics and control methods of the surrounding rock during the processes of driving, retaining, and reusing the roadway. Zhang et al. [5] introduced the control principle of integral reinforcement for gob-side entry retaining, based on a matching principle of support system stiffness on the roadway side. Han et al. [6] conducted a physical simulation experiment to illustrate the characteristics of the collapse of sequential overlying strata in goaf and its superposition disturbance mechanism with respect to gob-side entry retaining. Xue et al. [7] established a mechanical model of the rupture of an overburden structure with a $10 \mathrm{~m}$ thick 
hard roof and clarified the balance principle for a cantilever structure at the side of the goaf. Li et al. $[8,9]$ established a mechanical model of the key block and immediate roof and analysed the interaction mechanism between the key block and the surrounding rock of the gob-side entry retaining. Gao et al. [10] explored the transmission of blast stress waves in deep holes and the development law of rock mass fractures and explained the pressure relief principle of the deephole blasting of a gob-side entry retaining under a hard composite roof. Zhang and Chen [11, 12] established a mechanical model of gob-side entry retaining with hard roof cutting and presented a formula for calculating the cutting resistance of the filling body. Zhang et al. [13] studied the stability of the surrounding rock during reuse of a roadway constructed by roof cutting in a three-soft coal seam and clarified the spatial-temporal evolution law of the stress field and displacement field of the surrounding rock during the reuse period. He et al. [14-16] put forward a creative theory for roof cutting a short wall beam. On this basis, the technique of no-pillar mining was developed with gob-side entry obtained by advanced roof caving (110 method), which has been successfully applied and popularised in many mining areas. Wang et al. [17] studied the rheological breaking features of hard roof in gob. Deng et al. [18] studied the stress evolution and failure behaviour of the surrounding rock of the gob-side retaining entry with different depths, gob filling ratios, and gob-side filling widths and strengths. Based on the above results, systematic studies have been conducted on all stages of gob-side entry retaining, including the early, middle, and late stages. Research on the reuse of gob-side entry retaining has mainly focused on the stress distribution and deformation failure of the surrounding rock. Few studies have addressed the failure mechanism and stability of the precracked roof structure of a gob-side entry retaining during the reuse period, which requires further exploration.

In the reuse stage of gob-side entry retaining, the failure pattern and stability of the main roof structure have a great effect on the safety of the advanced support at the working face. In this work, the dynamic failure process and failure mechanism of the main roof in a gob-side entry retaining are investigated and classified at different stages of the mining process, with particular attention given to the formation process of the rock beam of the precracked main roof during the reuse period. A mechanical model is established of the rock beam structure in the precracked main roof during the reuse period to investigate the mutual feedback mechanical behaviour of the key blocks in the main roof. The formation conditions and influence factors of the rock beam structure in the precracked main roof during the reuse period are also clarified. Taking the gob-side entry retaining in the Huainan mining area as the engineering background, the research results were validated in industrial experiments.

\section{Engineering Geological Conditions}

Coal working face 1252 (1) and its adjacent coal face 1242 (1) in the eastern district of the Panyi coal mine are monoclinal structures with the main mining coal seam \#11-2. At the coal working face 1242 (1), the average dip angle of the coal seam is $4^{\circ}$, the ground elevation is $+21.5-22.1 \mathrm{~m}$, the floor elevation at the coal working area ranges from $-738.3 \mathrm{~m}$ to $-823.1 \mathrm{~m}$, and the average buried depth is greater than $800 \mathrm{~m}$. The maximum horizontal principal stress, which is distributed roughly in the east-west direction, is about $33.43 \mathrm{MPa}$, and its vertical stress is $19.80 \mathrm{MPa}$.

Figure 1 shows an illustration of the roadway layout of coal working faces 1252 (1) and 1242 (1). When coal working face 1252 (1) was being mined, a gob-side entry retaining with a total length of $1150 \mathrm{~m}$ was established in the section track drift, with the cross section size of the gob-side entry retaining of $4.2 \mathrm{~m}$ (width) $\times 3.2 \mathrm{~m}$ (height). Special filling materials for the coal mine are selected in accordance with the design of the roadside filling body, with the compressive strength of the concrete made from these materials reaching 32-36 MPa for a $3.0 \mathrm{~m}$ width of the filling body. The support of the roof and coal side is achieved using a "three-high" anchor bolt, large-diameter anchor cable, hollow grouting anchor cable, and grouting injection. To improve the overlying rock structure and stress environment of the gobside entry retaining, the presplitting blasting technique was used to force the hard roof of the gob-side entry retaining to develop a cracked weak surface at a certain height range. After the exhaustion of coal working face 1252 (1), the gobside entry retaining has continued to be used as a section track drift of coal working face 1242 (1).

\section{Formation Mechanism of Short Cantilever Rock Beam Structure of the Main Roof during Reuse Period}

Combining the failure forms of the presplitting gob-side entry retaining roof during the reuse period, theoretical analysis indicates the formation of three types of short cantilever rock beam structures in the gob-side entry retaining roof in the reuse period, namely, the "short cantilever-articulated rock beam" structure, "short cantilever step rock beam (type I)" structure, and "short cantilever step rock beam (type II)" structure.

\subsection{Formation Mechanism of Short Cantilever-Articulated Rock Beam Structure}

3.1.1. Formation Process of Short Cantilever-Articulated Rock Beam. In the first stage, when retaining the roadway along the goaf during mining of coal working face 1252 (1), the precracked roof behind the coal working face was broken along the weak fracture surface by the periodic weighting action, which formed key blocks $A, B$, and $C$ that were hinged together. Among them, key block $A$ was located directly above the reserved roadway and formed a short cantilever on the right side of the filling body, which successfully protected the retained roadway inside the overlying arch structure, as shown in Figure 2(a). This structure optimises the stress environment of the gob-side entry retaining roof. However, key block $B$ continues to exert a downward "pressure" effect on key block $A$. 


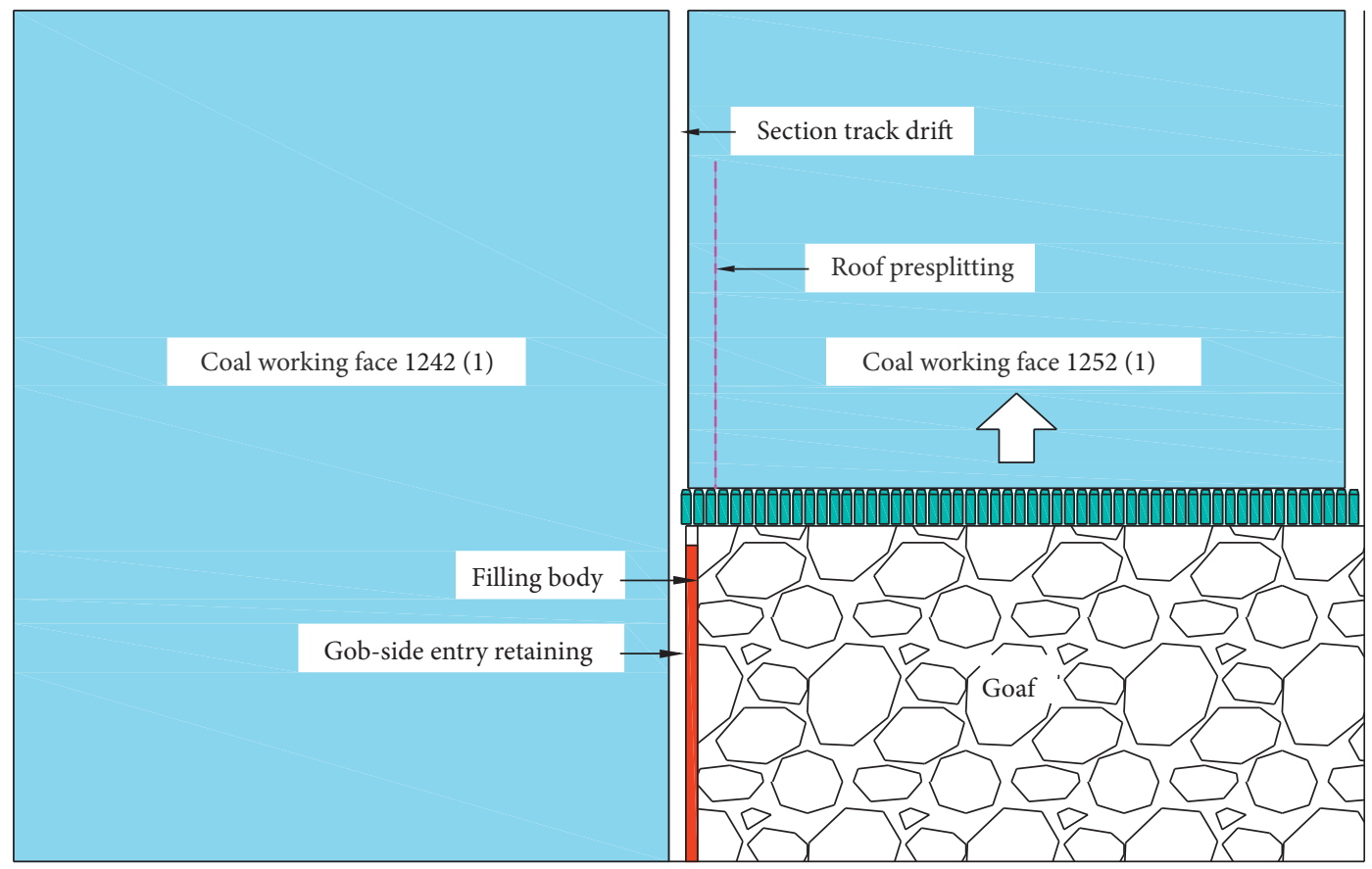

(a)

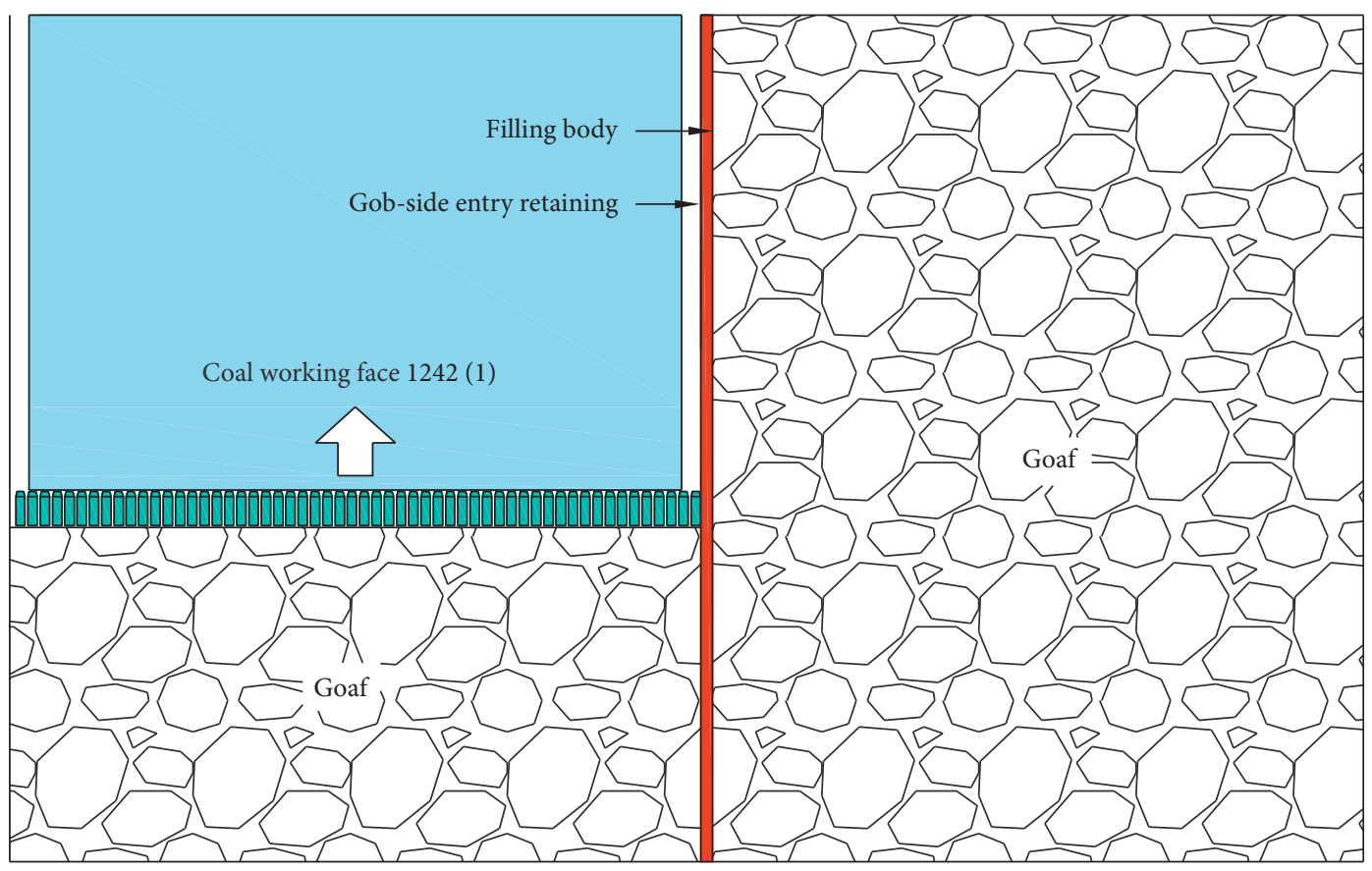

(b)

Figure 1: Roadway layout of two coal working faces. (a) In the stage of gob-side entry retaining; (b) in the reuse process of gob-side entry retaining.

In the second stage, when the gob-side entry was reused, the roadway roof in front of coal working face 1242 (1) was affected by the advanced abutment pressure of the coal working face and the residual abutment pressure of the stope side of the previous coal working face, which formed a stress superposition zone that connects the leading stress area with the stress superposition area. As shown in Figure 2(b), this formed region is close to the advanced support area at the end of the coal working face, which will greatly affect the stability of the gob-side entry retaining roof, leading to "secondary breaking" and rotary subsidence of the short cantilever rock beam in the advanced support area.

As the working face continues to advance, key block $B$ rotates anticlockwise as key block $A$ rotates clockwise and sinks. At this point, the hinged points of key blocks $A$ and $B$ gradually transferred from a lower to an upper hinge point. 


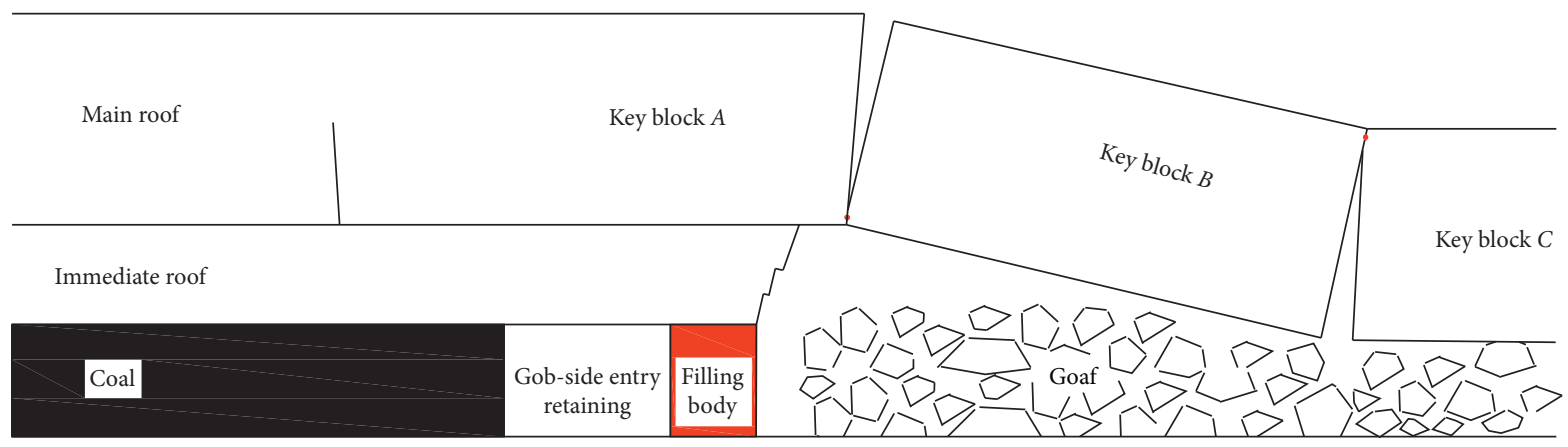

(a)

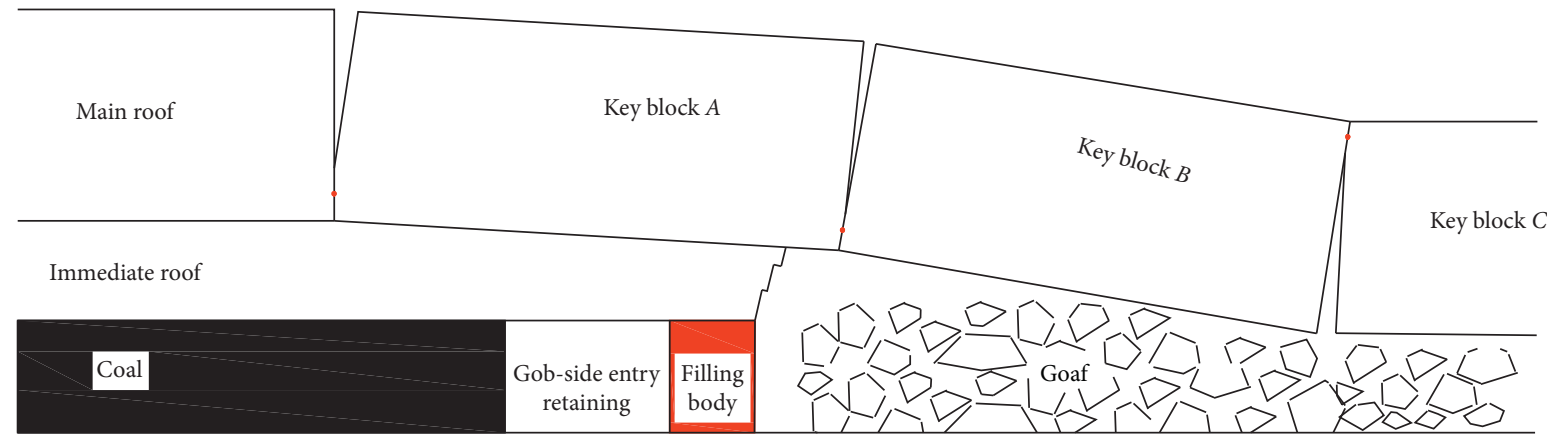

(b)

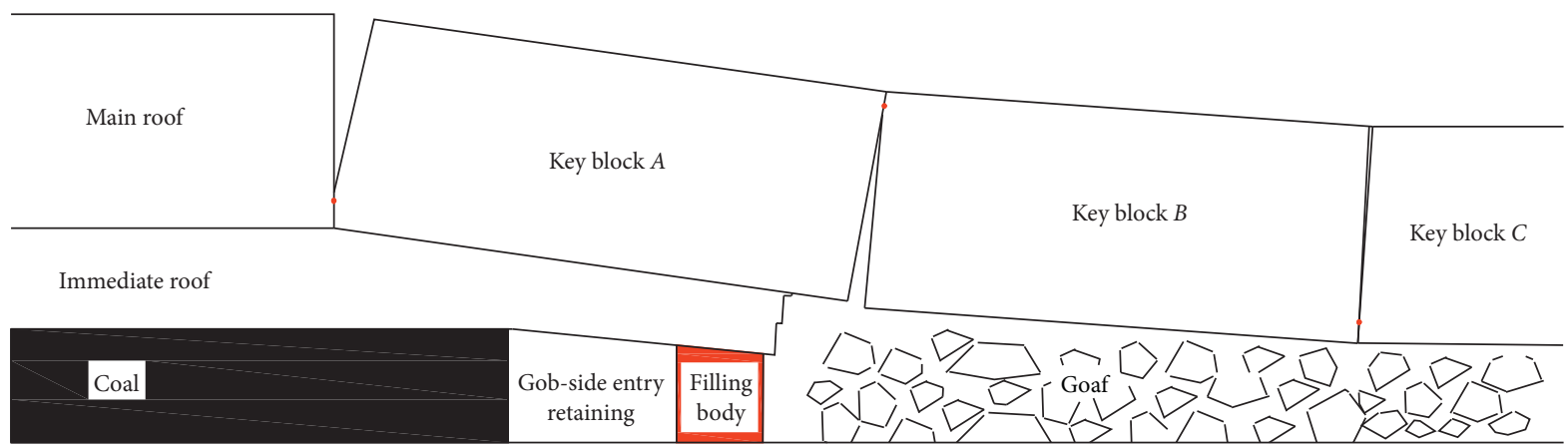

(c)

FIGURE 2: Structure form of short cantilever-articulated rock beam. (a) Roof structure in the stage of gob-side entry retaining, (b) roof structure in the early stage of reuse of gob-side entry retaining, and (c) the roof structure in the late stage of reuse of gob-side entry retaining.

The short cantilever-articulated rock beam structure, which is shown in Figure 2(c), also remains in a constant state of high-stress dynamic balance. This structure has a very harmful effect on the advanced support area of the gob-side entry retaining during the reuse period and greatly increases its instability, such that the roadway space can be greatly reduced or even collapse, causing the roof to fall.

\subsubsection{Mechanical Analysis of Short Cantilever-Articulated Rock Beam Structure}

(1) Establishment of Mechanical Model. Based on the above analysis, here, a mechanical model is established of the short cantilever-articulated rock beam structure of the gobside entry retaining roof during the reuse period. The interactional relationship among key blocks $A, B$, and $C$ is analysed from the mechanistic perspective. As shown in
Figure 3, the stability of a short cantilever-articulated rock beam structure is determined by the stability of key blocks $A$ and $B$ :

(1) The subsidence $\left(W_{2}\right)$ of key block $B$ is related to the thickness $\left(h_{0}\right)$ of the immediate roof, mining height $(m)$, and rock fragmentation coefficient $\left(k_{p}\right)$, for which the relationship formula is as follows [19]:

$$
W_{2}=m-\left(k_{p}-1\right) h_{0}
$$

(2) During the reuse period of the gob-side entry retaining, when the rotation angle $\left(\theta_{1}\right)$ of key block $A$ is zero, the maximum rotation angle $\left(\theta_{2 \max }\right)$ of key block $B$ can be calculated as follows:

$$
\theta_{2 \max }=\arcsin \frac{W_{2}}{L_{2}}
$$




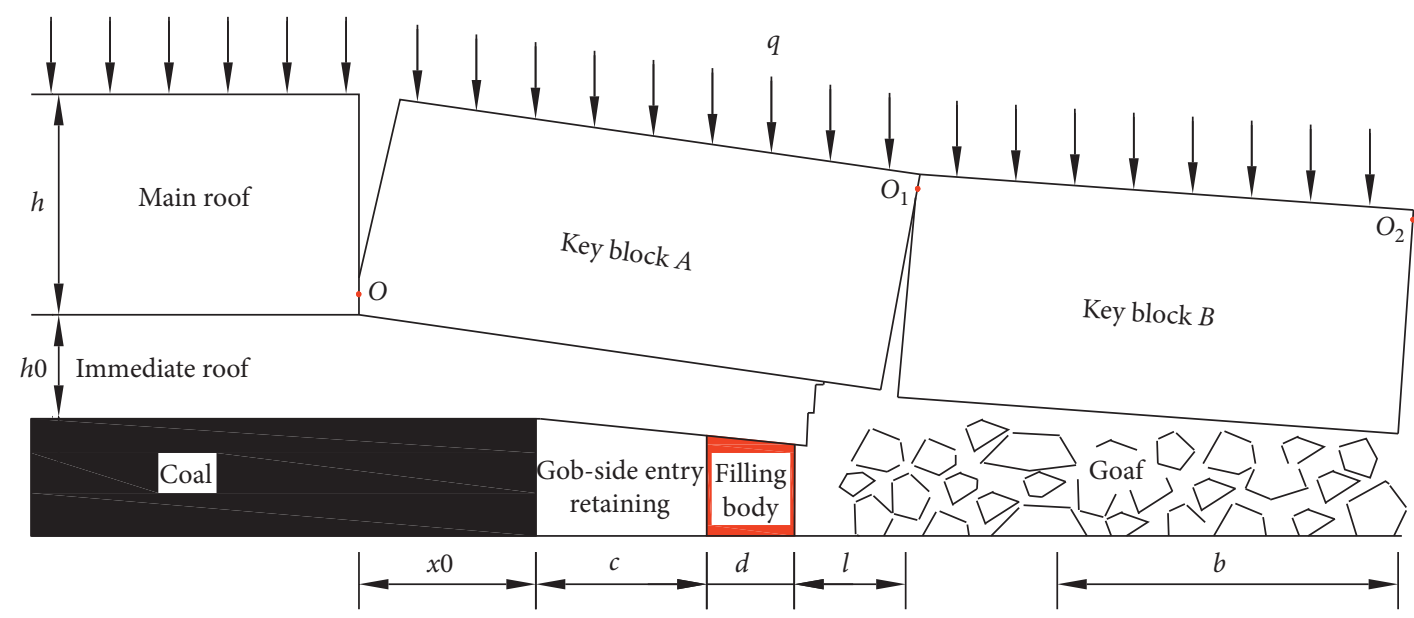

(a)

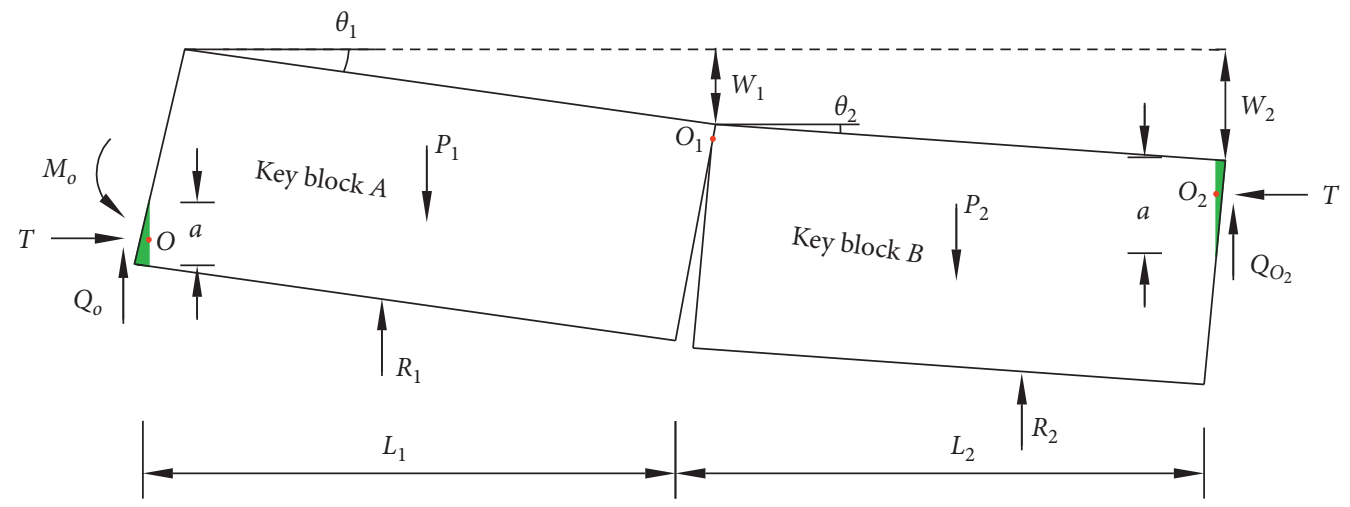

(b)

Figure 3: Mechanical model of short cantilever-articulated rock beam structure. (a) Diagrammatic sketch; (b) mechanical analysis chart.

where $L_{2}$ is the length of key block $B$. A rotation angle $\left(\theta_{2}\right)$ of $0 \leq \theta_{2}<\theta_{2 \max }$ indicates that key block $B$ is in contact with gangue and is supported by the gangue falling from the goaf. In this situation, the length $(b)$ of key block $B$ is expressed as $b=L_{2} \cos \theta_{2}$. The support reaction $\left(R_{2}\right)$ of the gangue in the goaf is calculated using the following formula [20]:

$$
R_{2}=\frac{1}{2} b K_{g}
$$

where $K_{g}$ is the support strength of the falling gangue.

(3) Based on the geometric contact relation of the key block rotary motion, the approximate height of the extruded contact surface of the corner in the key block is given by

$$
a=\frac{1}{2}\left(h-L_{1} \sin \theta_{1}\right)
$$

where $h(\mathrm{~m})$ is the thickness of the main roof, $L_{1}(\mathrm{~m})$ is the length of key block $A$, and $\theta_{1}$ is the rotation angle of key block $A$.

(4) The fracture line of key block $A$ is assumed to be located at the elastoplastic interface of the coal side.
According to the ultimate equilibrium theory, the width $\left(x_{0}\right)$ of the limit equilibrium zone in the coal side can be calculated using the following formula [21]:

$$
x_{0}=\frac{m A}{2 \tan \varphi_{0}} \cdot \ln \left(\frac{k \gamma H+\left(c_{0} / \tan \varphi_{0}\right)}{\left(c_{0} / \tan \varphi_{0}\right)+\left(p_{x} / A\right)}\right) \text {, }
$$

where $A$ is the lateral pressure, $H(\mathrm{~m})$ is the mining depth, $c_{0}(\mathrm{MPa})$ is the degree of cohesion of the coalrock interface, $\varphi_{0}$ is the internal friction angle of the coal-rock interface, $p_{x}$ is the supporting strength of the coal side, $k$ is the maximum stress concentration factor, and $\gamma\left(\mathrm{kN} / \mathrm{m}^{3}\right)$ is the average volume weight of the overlying rock.

(5) In the short cantilever step rock beam structure, the length of key block $A$ is calculated using

$$
L_{1}=x_{0}+c+d+l
$$

where $c(\mathrm{~m})$ is the roadway width, $d$ is the width of the filling body, and $l$ is the short cantilever length of the main roof at the side of the goaf.

For the short cantilever-articulated rock beam structure of the gob-side entry retaining roof during the reuse period, a second break of key block $A$ occurs. Three kinds of changes 
are evident in the form and load-bearing of its structural motion.

When $\theta_{2}=\theta_{2 \max }$ and $b=0$, this indicates that although a second break occurs in key block $A$, there is no obvious inclined subsidence of the roof. The roadway maintains full roof protection.

When $0<\theta_{2}<\theta_{2 \max }$ and $0<b<L$, this indicates that when a second break of key block $A$ occurs, obvious inclined subsidence of the roof occurs. The surrounding rock in the advanced support area exhibits relatively large deformation, which makes maintenance operations difficult.

When $\theta_{2}=0$ and $b=L$, this indicates that when a second break of key block $A$ occurs, severe inclined subsidence of the roof will occur, as well as severe deformation of the surrounding rock in the advanced support area, which makes maintenance operations very difficult.

Thus, it can be seen that as key block $A$ sinks at a clockwise incline, key block $B$ rotates anticlockwise. At this time, with a gradually increasing value of $\theta_{1}$, the rotation angle $\left(\theta_{2}\right)$ of key block $B$ decreases gradually and the area of key block $B$ in contact with gangue increases. Correspondingly, the supporting strength $R_{2}$ of the gangue on key block $B$ increases, which effectively improves the supporting force of key block $A$. However, the increased $\theta_{1}$ value causes a serious incline of the gob-side entry retaining roof during the reuse period, which is not conducive to the stability of the surrounding rock in the advanced support section of the gob-side entry retaining.

(2) Stress Analysis of Key Blocks. As shown in Figure 3, a stress analysis was performed of the short cantilever-articulated rock beam structure. To simplify the calculation, $L=L_{1}=L_{2}$. Based on the bending equilibrium of a square $\left(\sum M_{O}=0\right.$ and $\left.\sum M_{O 1}=0\right)$ with points $O$ and $O_{1}$, the formulas for determining the horizontal thrust $(T)$ and friction shear $\left(Q_{\mathrm{O} 2}\right)$ are obtained:

$$
\begin{aligned}
T= & \frac{L\left(P_{1}+P_{2}\right)-R_{1}(L-l)-R_{2} b-2 M_{O}}{2\left(h-a+W_{2}-2 W_{1}\right)} \\
Q_{O_{2}}= & \frac{\left[L\left(P_{1}+P_{2}\right)-R_{1}(L-l)-R_{2} b-2 M_{O}\right]\left(W_{2}-W_{1}\right)}{2 L\left(h-a+W_{2}-2 W_{1}\right)} \\
& +\frac{P_{2} L-R_{2}(2 L-b)}{2 L},
\end{aligned}
$$

where $W_{1}$ is the rotary subsidence height of key block $A, R_{1}$ is the supporting reaction force of the immediate roof, and $P_{1}$ $\left(P_{1}=q L_{1}\right)$ and $P_{2}\left(P_{2}=q L_{2}\right)$ are the load and self-weight of key blocks $A$ and $B$, respectively.

According to the geometric correspondence between the sinking amount of key block and the length of key block, $W_{1}=L \sin \theta_{1}, W_{2}=L\left(\sin \theta_{1}+\sin \theta_{2}\right)$, and $\sin \theta_{2} 0.25 \sin \theta_{1}$ are brought into formulas (7) and (8). Given $\sum F_{y}=0$, the final horizontal thrust $(T)$ and friction shear $\left(Q_{02}\right)$ can be derived from formulas (9) and (10):

$$
\begin{aligned}
T= & \frac{2 L\left(P_{1}+P_{2}\right)-2 R_{1}(L-l)-2 R_{2} b-4 M_{O}}{2 h-L \sin \theta_{1}}, \\
Q_{O}= & -\frac{\left[L\left(P_{1}+P_{2}\right)-R_{1}(L-l)-R_{2} b-2 M_{O}\right] \sin \theta_{1}}{2\left(2 h-L \sin \theta_{1}\right)} \\
& +P_{1}+\left(\frac{P_{2}}{2}\right)-R_{1}-\frac{R_{2}(4 L-b)}{2 L} .
\end{aligned}
$$

(3) Analysis of Stability of Short Cantilever-Articulated Rock Beam Structure. During the reuse of the gob-side entry retaining, the stability of key block $A$ is directly related to the stability of the surrounding rock. Using the "S-R" stability theory for a voussoir beam structure [22], the extrusion deformation instability and sliding instability of key block $A$ in the short cantilever-articulated rock beam structure can be obtained.

(1) Extrusion deformation instability

An increase in the rotation angle of key block $A$ will lead to deformation and instability of the short cantilever-articulated rock beam structure. The conditions for maintaining the stability of the structure are expressed as follows:

$$
T \leq a \eta \sigma_{c}
$$

where $\eta \sigma_{c}$ is the extrusion strength of the end angle of the key block.

Substituting formula (9) into formula (11), the supporting reaction force $\left(R_{1 \mathrm{i}}\right)$ in the presence of extrusion deformation instability can be calculated using

$$
R_{1 i} \geq \frac{2\left(P_{1}+P_{2}\right) L-2 R_{2} b-4 M_{O}-a \eta \sigma_{c}\left(2 h-L \sin \theta_{1}\right)}{2(L-l)} .
$$

(2) Sliding instability

The maximal shear force $\left(Q_{O}\right)$ on the short cantilever-articulated rock beam structure occurs at point $O$. To prevent instability of key block $A$ in the structure at point $O$, the following condition must be met:

$$
T \tan \varphi \geq Q_{O},
$$

where $\tan \varphi$ is the frictional coefficient between the key blocks, which has been determined in the laboratory to be 0.5 .

Substituting formulas (9) and (10) into formula (13), the range of the supporting reaction force $\left(R_{1 \mathrm{i}}\right)$ in the presence of sliding instability can be calculated using the following formula: 


$$
R_{1 i i} \geq \frac{\left[2 P_{1}+P_{2}-R_{2}(4 L-b) / L\right]\left(2 h-L \sin \theta_{1}\right)-\left[L\left(P_{1}+P_{2}\right)-R_{2} b-2 M_{O}\right]\left(2+\sin \theta_{1}\right)}{2\left(2 h-L \sin \theta_{1}\right)-(L-l)\left(2+\sin \theta_{1}\right)} .
$$

If key block $A$ is prevented from slipping and buckling and from buckling the extrusion deformation, the supporting reaction force of the immediate roof is at least as follows:

$$
R_{1}=\max \left(R_{1 i}, R_{1 i i}\right)
$$

\subsection{Formation Mechanism of Short Cantilever Step Rock Beam Structure}

3.2.1. Formation Process of Short Cantilever Step Rock Beam Structure. In the first stage, during the gob-side entry retaining process, with the mining of coal working face 1252 (1), the precracked roof behind the coal working face was broken along the fissure plane by the strong mining activity. The right side of key block $B$ was pressed onto the caved gangue. Simultaneously, a sliding phenomenon occurred at the left side, forming steps between key blocks $A$ and $B$, as shown in Figure 4(a). Key block $A$ was located directly above the gob-side entry retaining and formed a short cantilever on the right side of the filling body to successfully protect the retaining roadway inside the overlying arch structure. This structure is known as the short cantilever step rock beam. Although key block $B$ continues to exert downward pressure on key block $A$, the downward force of key block $B$ is significantly reduced compared with that of the short cantilever-articulated rock beam structure.

In the second stage, during the reuse period of the gobside entry retaining, the short cantilever beam may break again above the advanced support area of the gob-side entry retaining. As the coal working face continues to advance, key block $B$ rotates anticlockwise when key block $A$ rotates clockwise to sink. The hinge points of key blocks $A$ and $B$ gradually transfer from bottom to top. Clearly, after key block $B$ with reverse rotation becomes effectively stable, the effect of key block $B$ on $A$ changes from pressure to support, effectively preventing key block $A$ from sinking further. Figure 4(b) shows the final structure, which increases the stability of the advanced support area.

3.2.2. Mechanical Analysis of Short Cantilever Step Rock Beam Structure. Based on the above analysis, a mechanical model is established for the short cantilever step rock beam structure of the gob-side entry retaining roof during the reuse period, as shown in Figure 5.

The rotary sinking angle $\left(\theta_{1}\right)$ of key block $A$ can be calculated using

$$
\theta_{1}=\arcsin \frac{\left(W_{2}-s\right)}{L_{1}}
$$

where $s$ can be derived from the following equation:

$$
s=\left(h-\left(\frac{L_{1}-L_{1} \cos \theta_{1}+e}{\sin \theta_{1}}\right)\right) \cos \theta_{1}
$$

where $s(\mathrm{~m})$ is the step height between key blocks $A$ and $B$, $0 \leq s<W_{2}$, and $e(\mathrm{~m})$ is the width of the weak surface after presplitting blasting of the main roof.

(1) Stress Analysis of Short Cantilever Step Rock Beam (Type I) Structure. After key block $B$ falls, a step is formed between key blocks $B$ and $A$, with key block $A$ supported by key block $B$ at point $O_{1}$. At this time, key blocks $A$ and $B$ remain hinged by the interaction of horizontal forces, the mechanical model of which is shown in Figure 6.

Based on the model of the structural mechanics of the voussoir beam, the relationship can be approximately simplified as $R_{2}=P_{2}, Q_{O 2}=0$, and $L=L_{1}=L_{2}$. As shown in Figure 6, given $\sum F_{y}=0$ and $\sum M_{O}=0$, the friction shear $\left(Q_{O}\right)$ and horizontal thrust $(T)$ can be calculated using

$$
\begin{aligned}
Q_{O} & =P_{1}-R_{1}, \\
T & =\frac{P_{1} L-R_{1}(L-l)-2 M_{O}}{2\left(h-a-W_{2}\right)} .
\end{aligned}
$$

In the short cantilever step rock beam structure, key block $A$ is supported by key block $B$ at point $O_{1}$, which is characterised only by sliding instability (no rotary instability). It is easily determined that the maximum shear $\left(Q_{O}\right)$ of the short cantilever step rock beam structure occurs at point $O$. After substituting formulas (18) and (19) into formula (13), the supporting reaction force $\left(R_{1}\right)$ can be calculated using

$$
R_{1} \geq \frac{P_{1}\left[4\left(h-a-W_{2}\right)-L\right]+2 M_{O}}{\left[4\left(h-a-W_{2}\right)-L+l\right]} .
$$

(2) Stress Analysis of Short Cantilever Step Rock Beam (Type II) Structure. After key block $B$ falls, key blocks $A$ and $B$ are fully disconnected with no horizontal force transfer between them. The mechanical model of the short cantilever step rock beam (type II) structure can thus be simplified to the stress model of key block $A$ shown in Figure 7.

In the short cantilever step rock beam (type II) structure, when the horizontal thrust $(T)$ is zero, given $\sum M_{O}=0$, the stability of key block $A$ can be obtained using

$$
R_{1} \geq \frac{P_{1} L-2 M_{O}}{L-l} \text {. }
$$

\subsection{Discrimination of Structure of Short Cantilever Rock Beam}

\subsubsection{Discriminant Mechanical Model of Short Cantilever} Rock Beam Structure. Based on the analysis of the structural formation mechanism of the short cantilever rock beam of the gob-side entry retaining roof during the reuse period, the stability of key block $B$ is considered to affect the structural form of the short cantilever rock beam. A corresponding 


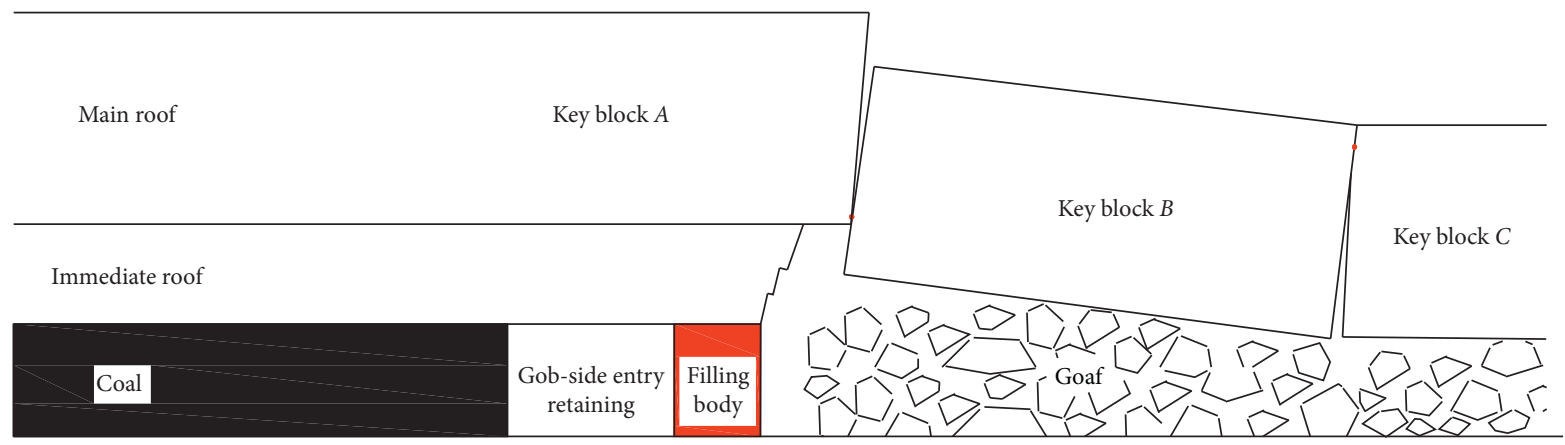

(a)

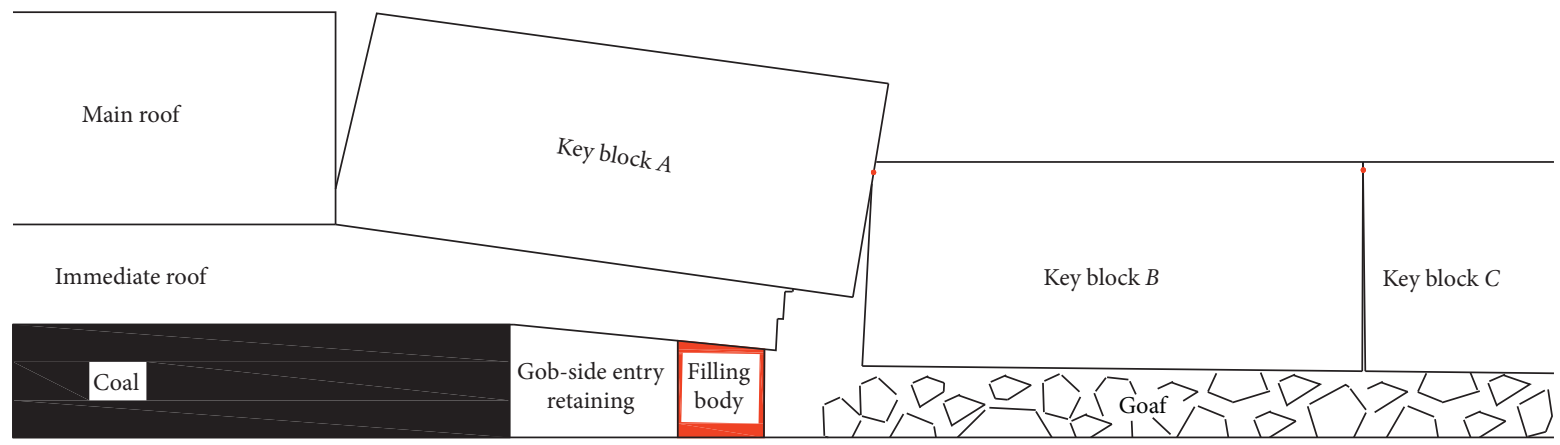

(b)

FIGURE 4: Structure form of short cantilever step rock beam. (a) Roof structure in the stage of gob-side entry retaining; (b) the roof structure in the reuse stage of gob-side entry retaining.

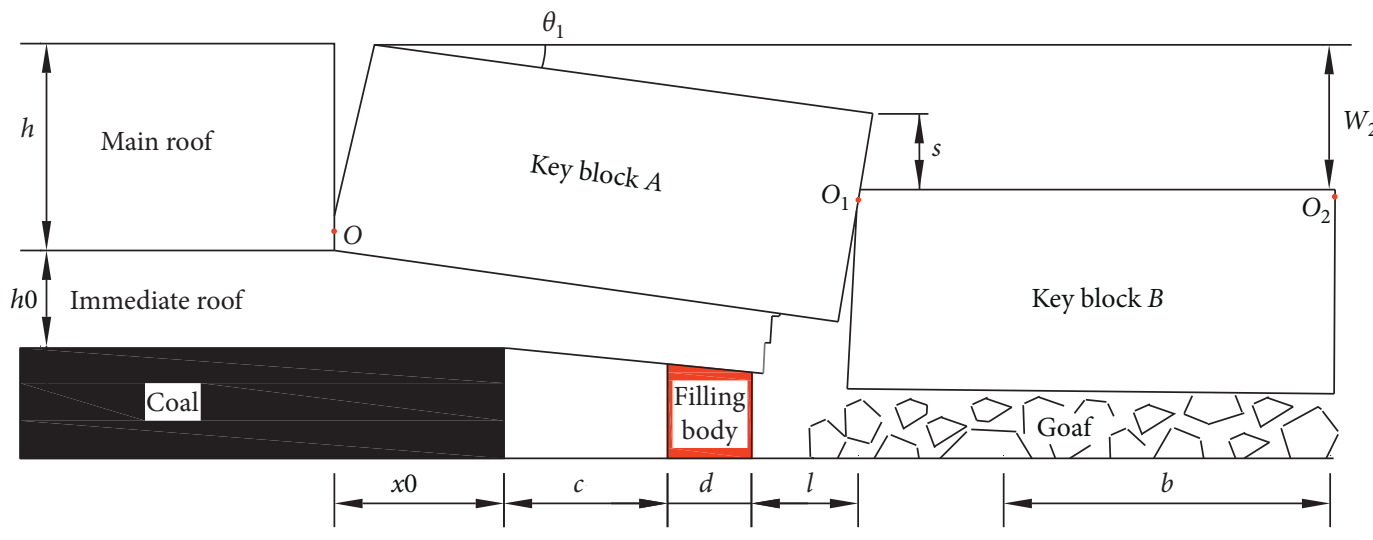

FIGURE 5: Structure model of short cantilever-step rock beam.

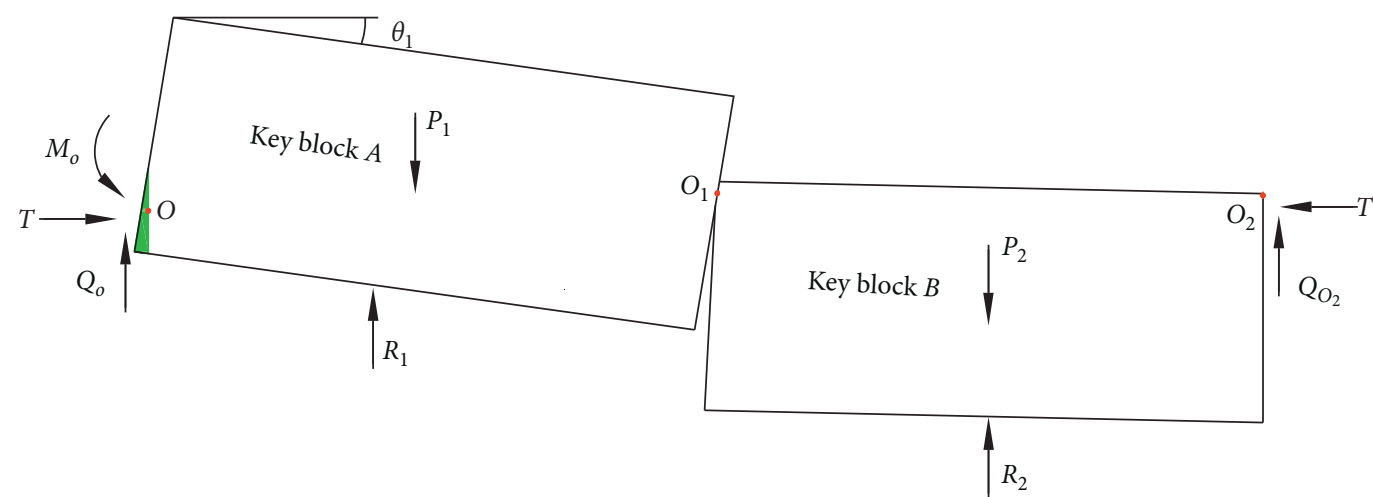

Figure 6: Interaction mechanics model between key blocks $A$ and $B(T \neq 0)$. 


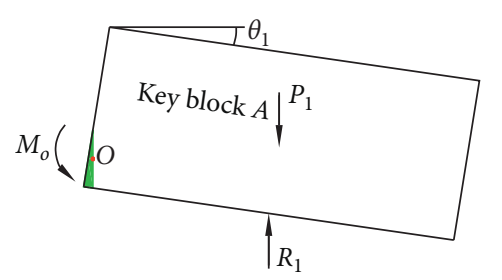

Figure 7: Mechanical model of key block $A(T=0)$.

mechanical model was established to analyse the structural form of the short cantilever rock beam of the gob-side entry retaining during the reuse period, as shown in Figure 8.

Suppose that the supporting force of the gangue in the goaf on key block $B$ is zero and the shear force on key block $B$ is $Q_{\mathrm{O} 2}$. When key block $B$ in the short cantilever rock beam structure is in a limit equilibrium state, formula (22) can be derived on the basis of $\sum M_{\mathrm{O} 2}=0$ :

$$
T\left(h-a-W_{20}\right)+\left(\frac{P_{2} L}{2}\right)-Q_{O_{1}} L=0 .
$$

The formula for calculating horizontal thrust $(T)$ is as follows $[23,24]$ :

$$
T=\frac{P_{2} L}{2\left(h-W_{20}\right)} .
$$

In conjunction with formulas (22) and (23), the shear force $\left(Q_{\mathrm{O} 2}\right)$ can be derived using

$$
Q_{O_{1}}=P_{2}\left[1-\frac{a}{2\left(h-W_{20}\right)}\right] \text {. }
$$

Based on the analysis of the formation mechanism of the short cantilever rock beam structure of the gob-side entry retaining roof during the reuse period, the stability requirements of the short cantilever-articulated rock beam and short cantilever step rock beam structures are considered to control the sliding and instability of the gob-side entry retaining roof. If key block $B$ slides to a certain height or less than that height and then becomes stable again, the limit equilibrium condition is $T \tan \varphi \geq Q_{O 1}$. The sliding instability coefficient $(K)$ can be calculated as follows:

$$
K=\frac{T \tan \varphi}{Q_{O_{1}}},
$$

and when $K \geq 1$, the short cantilever-articulated rock beam structure is formed without the sliding instability of key block $B$, whereby the higher the $K$-value is, the better the structural stability is. When $K<1$, key block $B$ will slip and become unstable.

During the sliding process of key block $B$, if the step hinges of key blocks $A$ and $B$ are once again in the equilibrium state, then a short cantilever step rock beam (type I) structure will form. At this time, the effect of key block $B$ on key block $A$ changes from pressure to "branch," which is beneficial to the stability of the gob-side entry retaining roof. If the horizontal force between the key blocks tends to 0 after the rotary sinking of key block $B$, then a short cantilever step rock beam (type II) structure will form.

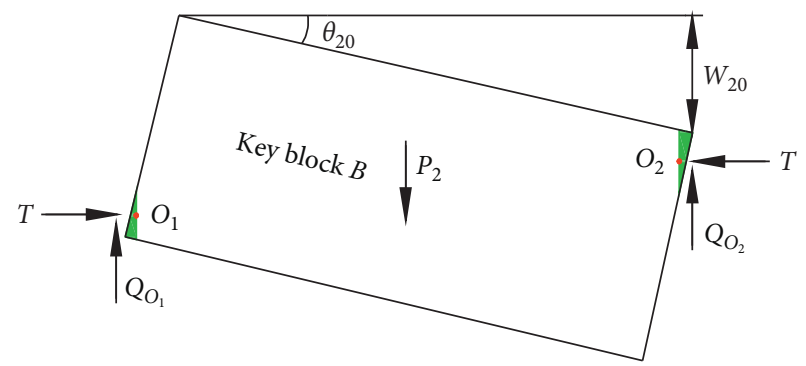

Figure 8: Mechanical model of key block $B$.

3.3.2. Limit Equilibrium Criterion for Short Cantilever Rock Beam Structure. Substituting formulas (1), (2), (4), (23), and (24) into formula (25) with $k_{p}=1.05$ and $\tan \varphi=0.5$, the formula for calculating the sliding instability coefficient $(K)$ is as follows:

$$
K=\frac{L}{3\left(h-m+0.05 h_{0}\right)},
$$

and, based on the equilibrium condition of the voussoir beam structure, that is, $L>2 h$, the ultimate formula for determining the equilibrium of the short cantilever rock beam structure is as follows:

$$
K=\frac{2 \mathrm{~h}}{3\left(h-m+0.05 h_{0}\right)},
$$

In this section, the occurrence of coal-series strata in the gob-side entry retaining in the Huainan mining area is considered and the fracture structure of the main roof is discussed. The variation range of relevant parameters at the coal working face can be summarised as follows: the thicknesses $(m)$ of the coal seams in different sections are $1.5 \mathrm{~m}, 2.1 \mathrm{~m}, 2.5 \mathrm{~m}, 2.8 \mathrm{~m}$, and $3.5 \mathrm{~m}$; the mudstone thickness (h) of the immediate roof varies from 0 to 10 ; and the mudstone thickness $(h)$ of the main roof varies from 0 to 20 . The variation law of the limit equilibrium state of the short cantilever rock beam structure is obtained by introducing the relevant parameters into formula (27) and then drawing 3D images, as shown in Figure 9.

As the thicknesses of the coal seams in Figures 9(a)-9(e) vary from $1.5 \mathrm{~m}$ to $3.5 \mathrm{~m}$, the limit equilibrium value $(K)$ of the short cantilever rock beam structure increases gradually. The $K$-value curve shows a sharp and then a gentle decline with increases in the thickness $(h)$ of the main roof. Simultaneously, this curve shows a slow decrease with increases in the thickness $\left(h_{0}\right)$ of the immediate roof. As the $K$-value decreases, the overburden structure gradually changes from a short cantilever-articulated rock beam structure $(K \geq 1)$ to a short cantilever step rock beam structure $(K<1)$.

\section{Influence of Short Cantilever Rock Beam on Roadway Side Support Structure}

4.1. Calculation of Filling-Body Load beside Roadway. Based on the structural characteristics of the surrounding rock of the gob-side entry retaining, a mechanical model of the surrounding-rock support structure is established, as shown in Figure 10. 


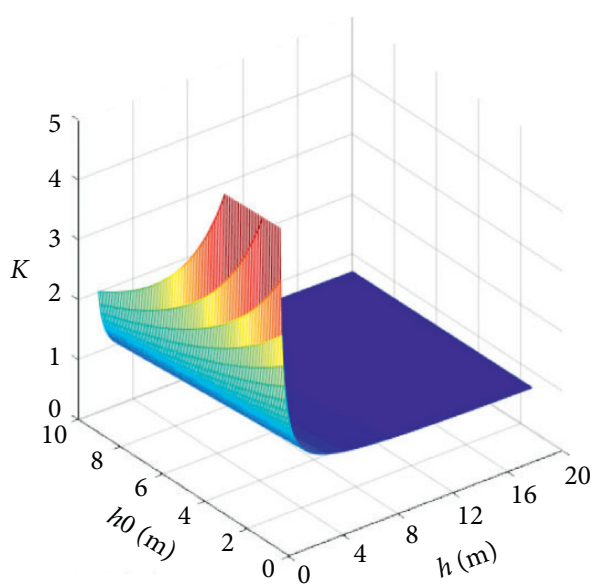

(a)

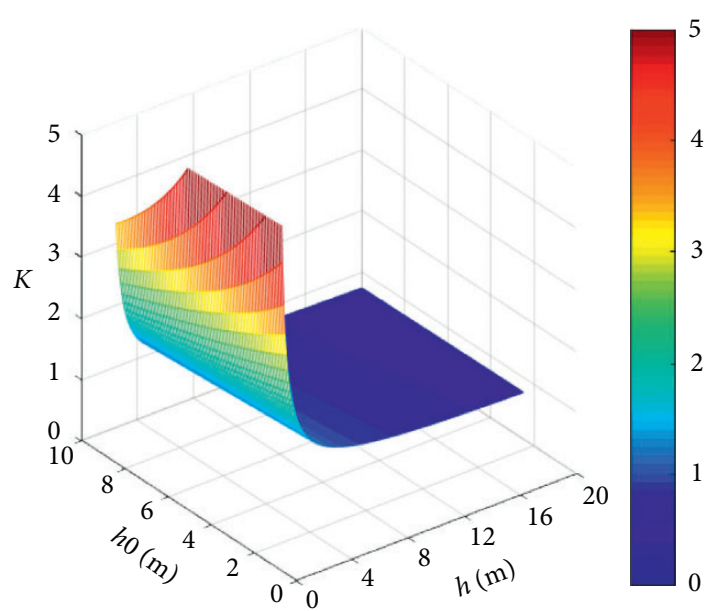

(c)

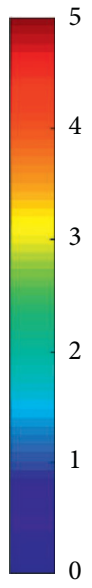

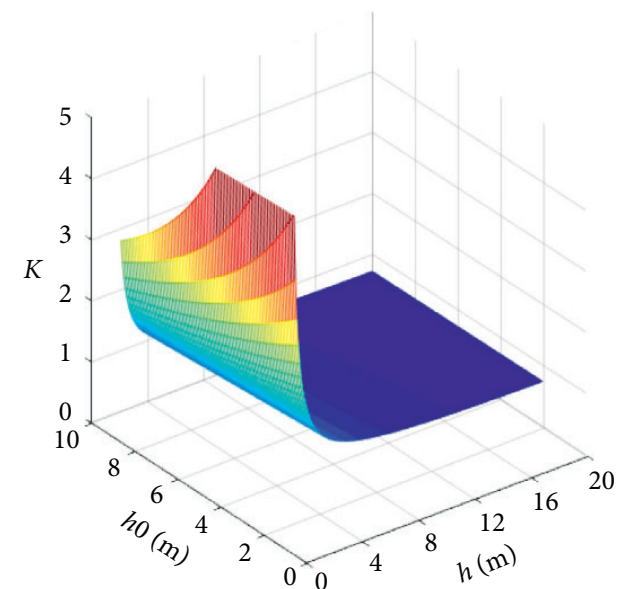

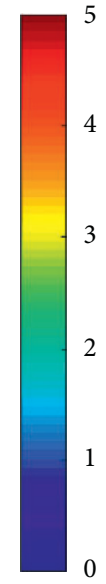

(b)

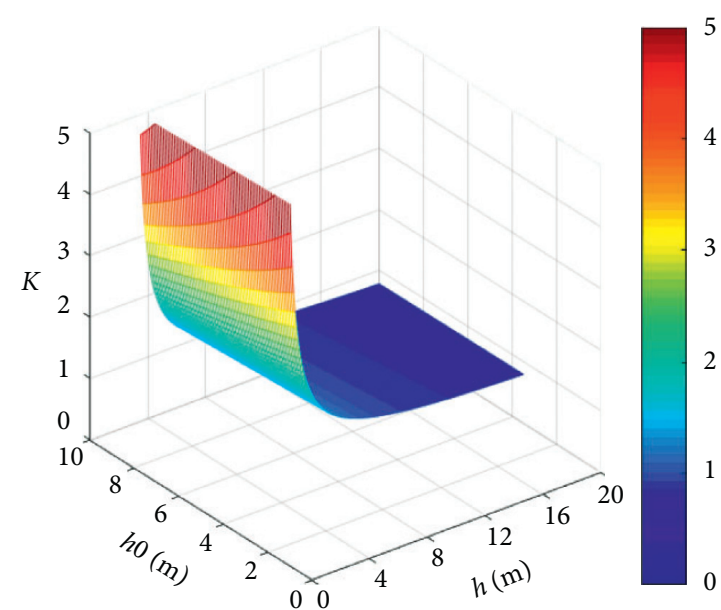

(e)

Figure 9: Limit equilibrium criterion of short cantilever rock beam structure. (a) $\mathrm{M}=1.5 \mathrm{~m}$ value, (b) $m=2.1 \mathrm{~m}$ value, (c) $m=2.5 \mathrm{~m}$ value, (d) $m=2.8 \mathrm{~m}$ value, and (e) $m=3.5 \mathrm{~m}$ value. 


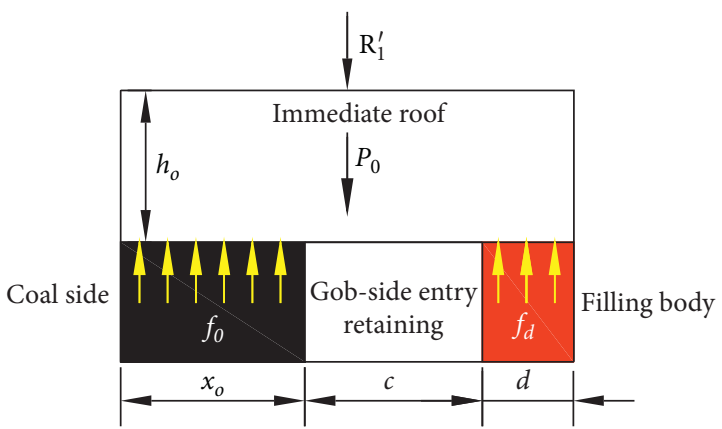

Figure 10: Mechanical model of surrounding rock support structure.

Given $\sum F y=0$ and $\sum M_{\text {Left }}=0$, the formula for calculating the filling-body load beside the roadway is given by formulas (28) and (29):

$$
\begin{gathered}
F_{0}+F_{d}-P_{0}-R_{1}^{\backslash}=0, \\
\frac{F_{0} x_{0}}{2}+F_{d}\left(x_{0}+c+\frac{d}{2}\right)-\frac{\left(R_{1}^{\backslash}+P_{0}\right)\left(x_{0}+c+d\right)}{2}=0,
\end{gathered}
$$

where $h_{0}$ and $P_{0}$ are the thickness and deadweight of the immediate roof, respectively, $R_{1}$ is the reaction load of key block $A$ on the upper boundary of the immediate roof, and $F_{0}$ and $F_{d}$ are the force of the coal-side support to the immediate roof and supporting resistance of the filling body, respectively, with $R_{1}{ }^{\prime}, F_{0}$, and $F_{d}$ given by $R_{1}{ }^{~}=-R_{1}, F_{0}=f_{0} x_{0}$, and $F_{d}=f_{d} d$. The residual bending moment at the left end of the immediate roof is ignored.

Based on formulas (28) and (29), the support resistance of the filling body can be easily derived as follows:

$$
F_{d}=\frac{\left(R_{1}^{\backslash}+P_{0}\right)(c+d)}{x_{0}+2 c+d} .
$$

Formulas (15), (20), and (21) are introduced into formula (30). respectively, to obtain the formula for calculating filling loads $F_{d 1}, F_{d 2}$, and $F_{d 3}$, respectively, which correspond to the short cantilever-articulated rock beam, short cantilever step rock beam (type I), and short cantilever step rock beam (type II) structures.

If key block $A$ has no slipping instability or extrusion deformation instability, the supporting resistance of the filling body can be calculated as follows:

$$
F_{d}=\max \left(F_{d 1}, F_{d 2}, F_{d 3}\right),
$$

and, given $F_{d}=f_{d} d$, the above formula can be simplified as follows:

$$
f_{d}=\max \left(f_{d 1}, f_{d 2}, f_{d 3}\right)
$$

During the reuse period of the gob-side entry retaining, the short cantilever rock beam structure changes depending on the overburden conditions in different sections, so each of the short cantilever-articulated rock beam, short cantilever step rock beam (type I), and short cantilever step rock beam (type II) structures can occur. Therefore, to ensure the stability of the overburden structure, the support resistance value on the roadway side is generally determined based on the theoretical maximum value.

\subsection{Load of Filling Body under Different Short Cantilever Rock} Beam Structures. The total length of the gob-side entry retaining in coal working face 1242 (1) is $1150 \mathrm{~m}$, with three typical sections with different roof conditions. In Section 1, $m=2.1 \mathrm{~m}, h=8 \mathrm{~m}$, and $h_{0}=3 \mathrm{~m}$. In Section $2, m=2.5 \mathrm{~m}$, $h=5 \mathrm{~m}$, and $h_{0}=7 \mathrm{~m}$. In Section $3, m=2.8 \mathrm{~m}, h=7 \mathrm{~m}$, and $h_{0}=6 \mathrm{~m}$. Other parameters are as follows: $A=0.4, \varphi_{0}=36^{\circ}$, $k=2.5, \gamma=24 \mathrm{kN} / \mathrm{m}^{3}, H=800 \mathrm{~m}, c_{0}=0.3 \mathrm{MPa}, p_{x}=0.2 \mathrm{MPa}$, $c=4.2 \mathrm{~m}, l=3 \mathrm{~m}, d=3.0 \mathrm{~m}, q=150 \mathrm{kN} / \mathrm{m}, h_{0}=2 \mathrm{~m}, k_{p}=1.05$, $\eta=0.8, K_{g}=1.5 \mathrm{MPa} / \mathrm{m}^{2}$, and $\sigma_{c}=60 \mathrm{MPa}$. These parameters are calculated using formulas (1)-(32), and the sliding instability coefficient $(K)$ values and the filling-body loads are summarised in Table 1.

Given the sliding instability coefficient $K$-value of the short cantilever rock beam structure, the roof structures of sections 1,2, and 3 correspond to the short cantilever-articulated rock beam structure, short cantilever step rock beam (type I) structure, and short cantilever step rock beam (type II) structure, respectively. The loading value of the filling body in the short cantilever-articulated rock beam structure is more than three times that of the short cantilever step rock beam (type I or II) structure. As such, the structural form of the short cantilever step rock beam is clearly the most favourable for gob-side entry retaining during the reuse period.

\subsection{Analysis of Roadway Side Support of Short Cantilever Rock Beam Structure}

4.3.1. Load on the Filling Body. During the reuse period of the gob-side entry retaining at coal working face 1241 (1), a group of stations for monitoring the filling-body load was arranged on the roadside filling bodies of sections 1, 2, and 3 . Three YZ-type hydraulic pillows with $3 \mathrm{~m}$ spacing were arranged in each test station to observe the loads on the filling bodies.

Figure 11 presents the final observation data obtained by the test stations, in which it can be easily seen that the average readings of the three YZ-type hydraulic pillows in sections 1,2 , and 3 are, respectively, $0.63 \mathrm{MPa}, 2.74 \mathrm{MPa}$, and $2.27 \mathrm{MPa}$. The average readings in sections 2 and 3 are 4.35 and 3.60 times higher than those in section 1, respectively. These results prove that the uniform load on the filling body in the short cantilever-articulated rock beam structure is more than three times those of the short cantilever step rock beam (types I and II) structures during the reuse period of the gob-side entry retaining. Moreover, the range and degree of violent activity of the short cantilever-articulated rock beam structure are greater than those of the short cantilever step rock beam (types I and II) structures. 
TABLE 1: Loading value of filling body in typical section.

\begin{tabular}{lcr}
\hline Serial number & $K$ & The load of filling body (MPa) \\
\hline Section 1 & 0.882 & 0.510 \\
Section 2 & 1.170 & 1.931 \\
Section 3 & 1.037 & 1.655 \\
\hline
\end{tabular}

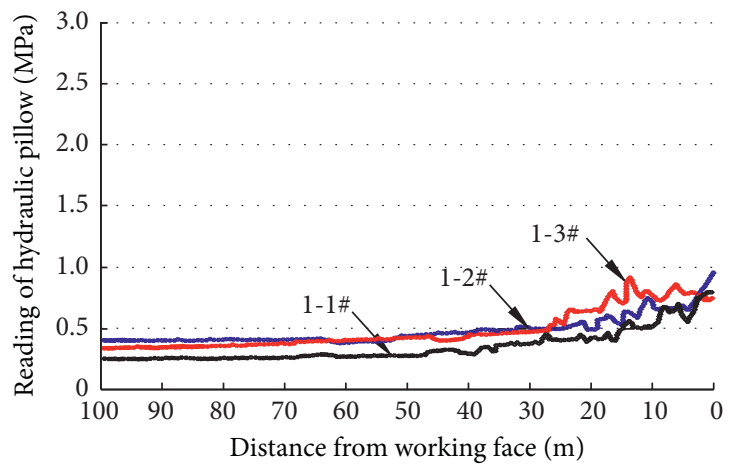

(a)

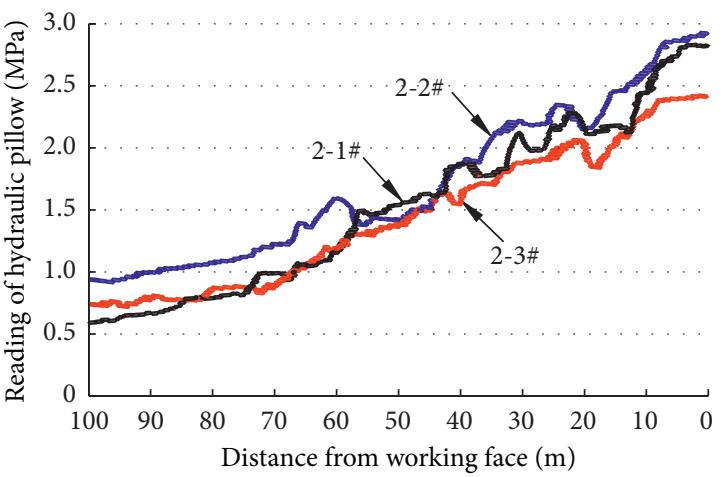

(b)

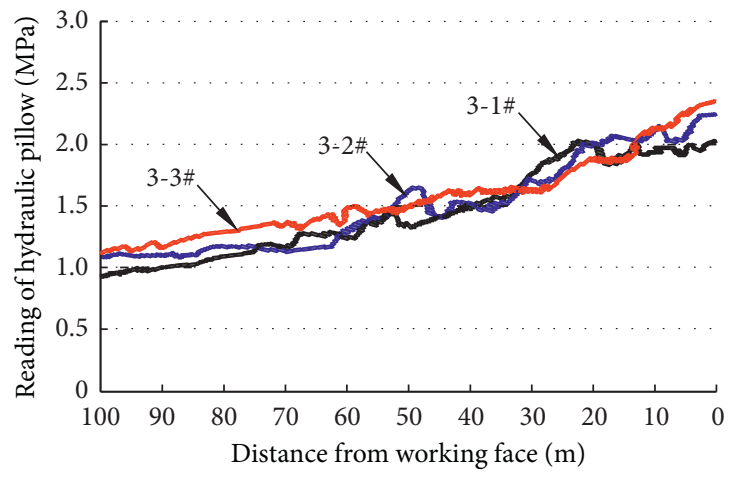

(c)

Figure 11: Stress state curve of the filling body during the reuse period of gob-side entry retaining. (a) Stress state of the filling body at station 1, (b) stress state of the filling body at station 2, and (c) stress state of the filling body at station 3.

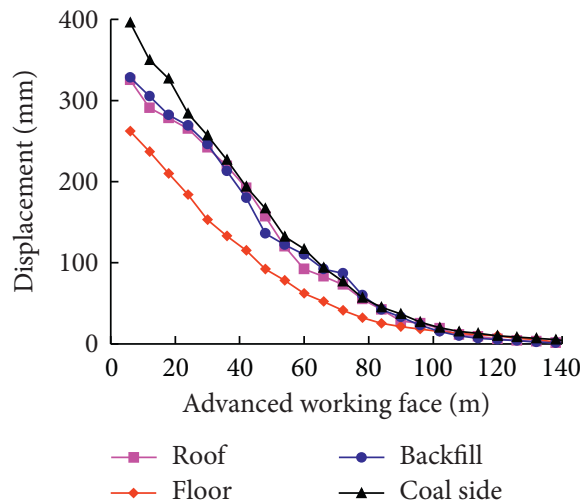

(a)

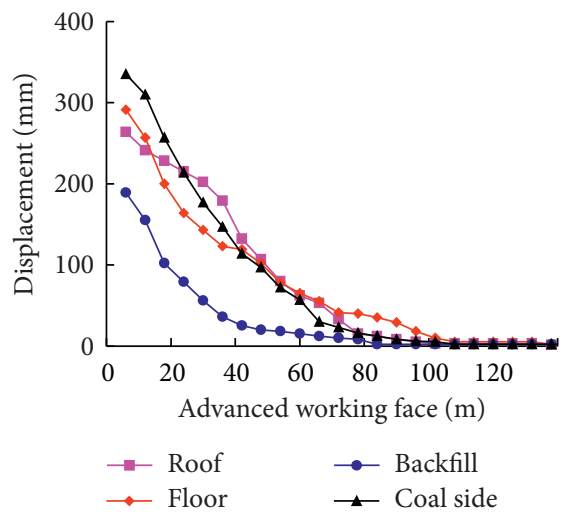

(b)

Figure 12: Displacement curve of surrounding rock with the mining of working face. (a) Displacement curve of surrounding rock in section 1; (b) displacement curve of surrounding rock in section 2 . 


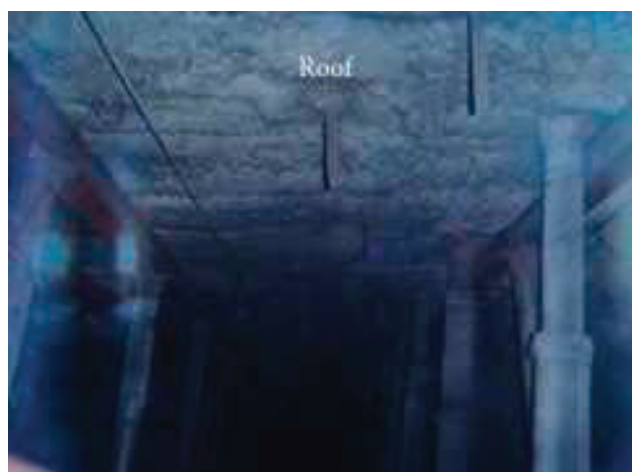

(a)

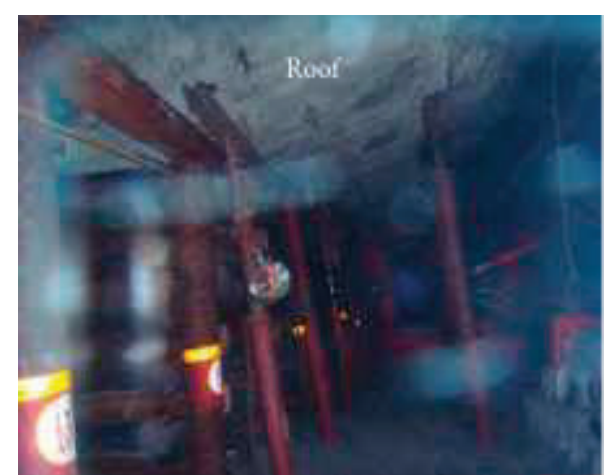

(b)

FIGURE 13: Roof form of the gob-side entry retaining in the reuse period. (a) Roof form in section 1; (b) roof form in section 2.

\subsubsection{Deformation and Destruction of Gob-Side Entry} Retaining during Reuse Period. During the reuse period of the gob-side entry retaining, the deformation and failure of the surrounding rock within $140 \mathrm{~m}$ of the front of coal working face 1242 (1) are shown in Figure 12.

The average subsidence and rotation tilt of the roof are about $294 \mathrm{~mm}$ and $8-13^{\circ}$, respectively. Although the filling body is inclined at the same angle as the roof, its integrity is good. The average displacement values of the coal side and floor are approximately $365 \mathrm{~mm}$ and $276 \mathrm{~mm}$, respectively. Figure 13 shows an illustration of the good maintenance state of the surrounding rock of the gob-side entry retaining in the reuse period, wherein the cross section of the gob-side entry retaining meets mining requirements.

\section{Conclusions}

(1) In this paper, the formation process of the short cantilever rock beam of the gob-side entry retaining during the reuse period was clarified, in which three types of short cantilever rock beam structures occur in the gob-side entry retaining roof, namely, short cantilever-articulated rock beam, short cantilever step rock beam (type I), and short cantilever step rock beam (type II) structures.

(2) To obtain the limit equilibrium criterion of the different short cantilever beam structures, mechanical models were established for the short cantilever beam structures and surrounding-rock supporting structure of the gob-side entry retaining during the reuse period. The results reveal that when the sliding instability coefficient $K \geq 1$, a short cantilever-articulated rock beam structure forms. When the sliding instability coefficient $K<1$, a short cantilever step rock beam (type I or II) structure forms.

(3) The governing law for the stability of the thicknesses of the main roof, immediate roof, and coal seam on the short cantilever rock beam structure was clarified, which is mainly reflected in the following three respects: (1) with increases in the thickness of the coal seam, the limit equilibrium value $(K)$ of the short cantilever rock beam structure increases gradually; (2) the $K$-value curve shows a sharp and then a gentle decline with the increasing thickness $(h)$ of the main roof; and (3) the $K$-value curve shows a slow decreasing trend with the increasing thickness $\left(h_{0}\right)$ of the immediate roof. As the $K$-value decreases, the overburden structure gradually changes from a short cantilever-articulated rock beam structure $(K \geq 1)$ to a short cantilever step rock beam structure $(K<1)$.

\section{Data Availability}

All data used to support the findings of this study are included within the article, and there are not any restrictions on data access.

\section{Conflicts of Interest}

The authors declare no conflicts of interest.

\section{Acknowledgments}

This research was financially supported by the National Natural Science Foundation of China (nos. 51804129, 51904110, 51904112, and 51904113), the General Program of China Postdoctoral Science Foundation (no. 2020M671301), the Postdoctoral Science Foundation of Jiangsu Province (nos. 2019K139 and 2019Z107), the Huai'an Science and Technology Plan project (no. HAB201836), the Natural Science Foundation of the Jiangsu Higher Education Institutions of China (Project Principals Chunlei Zhang), the Jiangsu Natural Science Foundation Project (no. BK20181061), the Industry Education Research Cooperation Projects in Jiangsu Province (no. BY2020007), and the 2019 Huaishang Talent Plan Program (Project Principals Jingke $\mathrm{Wu})$.

\section{References}

[1] S. R. Xie, Q. Zhang, D. D. Chen et al., "Research and application of asymmetric anchorage deep beam bearing structure model in gob-side entry retaining roof," Journal of Mining \& Safety Engineering, vol. 37, no. 2, pp. 298-310, 2020. 
[2] G. R. Feng, Y. Q. Ren, and P. F. Wang, "Stress distribution and deformation characteristics of roadside backfill body for gobside entry of fully-mechanized caving in thick coal seam," International Journal of Mining Science and Technology, vol. 36, no. 6, pp. 1109-1119, 2019.

[3] H. P. Kang, D. L. Niu, Z. Zhang et al., "Characteristics of surrounding rock deformation and supporting technology of gob-side entry retaining in deep coal mine," Chinese Journal of Rock Mechanics and Engineering, vol. 29, no. 10, pp. 19771987, 2010.

[4] H. P. Kang, L. X. Yan, X. P. Guo et al., "Characteristics of surrounding rock deformation and reinforcement technology of retained entry in working face with multi-entry layout," Chinese Journal of Rock Mechanics and Engineering, vol. 31, no. 10, pp. 2022-2036, 2012.

[5] N. Zhang, C. L. Han, J. G. Kan et al., "Theory and practice of surrounding rock control for pillarless gob-side entry retaining," Journal of China Coal Society, vol. 39, no. 8, pp. 1635-1641, 2014.

[6] C. L. Han, N. Zhang, Z. Ran, R. au, and H. Q Yang, "Superposed disturbance mechanism of sequential overlying strata collapse for gob-side entry retaining and corresponding control strategies," Journal of Central South University, vol. 25, no. 9, pp. 2258-2271, 2018.

[7] J. H. Xue and C. R. Duan, "Technologies of gob-side entry retaining with no-pillar in condition of overlying and thickhard roof," Journal of China Coal Society, vol. 39, no. S2, pp. 378-383, 2014.

[8] Y. F. Li and X. Z. Hua, "Mechanical analysis of stability of key blocks of overlying strata for gob-side entry retaining and calculating width of roadside backfill," Rock and Soil Mechanics, vol. 33, no. 4, pp. 1134-1140, 2012.

[9] Y. F. Li and X. Z. Hua, "Mechanical analysis on the stability of surrounding rock structure of gob-side entry retaining," Journal of China Coal Society, vol. 42, no. 9, pp. 2262-2269, 2017.

[10] K. Gao, Z. G. Liu, D. S. Deng et al., “Application of deep borehole blasting to gob-side entry retaining forced roof caving in hard and compound roof deep well," Chinese Journal of Rock Mechanics and Engineering, vol. 32, no. 8, pp. 1588-1594, 2013.

[11] Z. Z. Zhang, J. B. Bai, Y. Chen et al., "Shallow-hole blasting mechanism and its application for gob-side entry retaining with thick and hard roof," Chinese Journal of Rock Mechanics and Engineering, vol. 35, no. S1, pp. 3008-3017, 2016.

[12] Y. Chen, S. P. Hao, and Y. T. Chen, "Study on the application of short-hole blasting with guide hole to roof cutting pressure relief of gob-side entry retaining," Journal of Mining \& Safety Engineering, vol. 32, no. 2, pp. 253-259, 2015.

[13] Y. Zhang, F. x. Shen, X. M. Sun et al., "Stress and deformation law of surrounding rock in the second reuse of roadway formed by roof cutting in the "three soft" coal seam," Journal of China University of Mining \& Technology, vol. 49, no. 2, pp. 247-254, 2020.

[14] M. C. He, Y. J. Wang, J. Yang et al., "Zonal characteristics and its influence factors of working face pressure using roof cutting and pressing-relief mining method with no pillar and road way formed automatically," Journal of China University of Mining \& Technology, vol. 47, no. 6, pp. 1157-1165, 2018.

[15] M. C. He, Y. B. Gao, J. Yang et al., "Engineering experimentation of gob-side entry retaining formed by roof cutting and pressure release in a thick-seam fast-extracted mining face," Rock and Soil Mechanics, vol. 39, no. 1, pp. 254-264, 2018.
[16] Y. J. Wang, M. C. He, J. Yang et al., "The structure characteristics and deformation of "short cantilever beam" using a non-pillar mining method with gob-side entry formed automatically," Journal of China University of Mining \& Technology, vol. 48, no. 4, pp. 718-726+759, 2019.

[17] J. A. Wang, D. Z. Li, and X. C. Shang, "Creep failure of roof stratum above mined-out area," Rock Mechanics and Rock Engineering, vol. 45, no. 4, pp. 533-546, 2012.

[18] X. J. Deng, C. W. Dong, Z. X. Yuan et al., "Deformation behavior of gob-side filling body of gob-side retaining entry in the deep backfilling workface," Journal of Mining \& Safety Engineering, vol. 37, no. 1, pp. 62-72, 2020.

[19] M. G. Qian, Collection of Papers on Strata Control and Scientific Coal Mining, pp. 45-51, China University of Mining and Technology Press, Xuzhou, China, 2011.

[20] M. G. Qian, P. W. Shi, and J. L. Xu, Mining Pressure and Strata Control, pp. 107-112, China University of Mining and Technology Press, Xuzhou, China, 2010.

[21] C. L. Han, N. Zhang, B. Y. Li, and X. G. Zheng, "Pressure relief and structure stability mechanism of hard roof for gob-side entry retaining," Journal of Central South University, vol. 22, no. 11, pp. 4445-4455, 2015.

[22] J. L. Xu, W. B. Zhu, X. Z. Wang et al., "Classification of key strata structure of overlying strata in shallow coal seam," Journal of China Coal Society, vol. 34, no. 7, pp. 865-870, 2009.

[23] J. L. Xu, D. Y. Xuan, W. B. Zhu et al., "Partial backfilling coal mining technology based on key strata control," Journal of Mining and Strata Control Engineering, vol. 1, no. 1, Article ID 013504, 2019.

[24] N. Jiang, C. Wang, H. Pan et al., "Modeling study on the influence of the strip filling mining sequence on mining-induced failure," Energy Science \& Engineering, vol. 1, pp. 1-17, 2020. 